\title{
Guillain-Barré syndrome following COVID-19: a newly emerging post-infectious complication
}

\author{
Silas Webb, ${ }^{1}$ Victoria CJ Wallace, ${ }^{2}$ David Martin-Lopez, ${ }^{3}$ Mahinda Yogarajah ${ }^{2}$
}

${ }^{1}$ Department of Intensive Care, St George's University Hospitals NHS Foundation Trust, London, UK

${ }^{2}$ Department of Neurology, St George's University Hospitals NHS Foundation Trust, London, UK

${ }^{3}$ Department of

Neurophysiology, St George's University Hospitals NHS Foundation Trust, London, UK

\section{Correspondence to} Dr Silas Webb;

silaswebb1@googlemail.com

SW and VCW are joint first authors.

Accepted 27 May 2020

Check for updates

(c) BMJ Publishing Group Limited 2020. No commercial re-use. See rights and permissions. Published by BMJ.

To cite: Webb S, Wallace VCJ Martin-Lopez D, et al. BMJ Case Rep 2020;13:e236182. doi:10.1136/bcr-2020-

236182

\section{SUMMARY}

A 57-year-old man presented with a progressive flaccid symmetrical motor and sensory neuropathy following a 1-week history of cough and malaise. He was diagnosed with Guillain-Barré syndrome secondary to COVID-19 and started on intravenous immunoglobulin. He proceeded to have worsening respiratory function and needed intubation and mechanical ventilation. This is the first reported case of this rare neurological complication of COVID-19 in the UK, but it adds to a small but growing body of international evidence to suggest a significant association between these two conditions. Increasing appreciation of this by clinicians will ensure earlier diagnosis, monitoring and treatment of patients presenting with this.

\section{BACKGROUND}

Severe acute respiratory syndrome coronavirus 2 (SARS-CoV-2) is causing a worldwide pandemic of COVID-19. As case numbers increase, the body of research around SARS-CoV-2 and the pathophysiology of the disease process it causes (COVID-19), expands daily. Patients with COVID-19 typically present with fever and respiratory illness; however, a wide range of other symptoms have been described. While the neurological sequelae of the virus remain poorly understood, there are a growing number of reports of neurological manifestations of COVID-19. ${ }^{1}$ A recent study from Wuhan reported that $78(36.4 \%)$ out of 214 patients admitted with COVID-19 had neurological symptoms ranging from anosmia and taste disturbances to cerebrovascular to strokes and seizures. ${ }^{1}$

Additionally, there is increasing recognition of a link between COVID-19 and Guillain-Barré syndrome (GBS), with three international case reports and one case series of five patients as the only published cases to date. ${ }^{2-5}$ To help add to this small but developing body of evidence, this is the first published case of GBS secondary to COVID-19 in the UK.

\section{CASE PRESENTATION}

On 13 April 2020, a 57-year-old, right-handed man with a medical history of untreated hypertension and psoriasis presented to the emergency department with a 1-day history of progressive limb weakness and foot dysaesthesia. On the evening prior to admission, he noted that he had some difficulty standing unaided and noticed some tingling sensations in his feet. The next morning, he was unable to stand, and his arms felt weak. Incidentally, he also reported a 1 week history of mild cough and headache, myalgia and malaise. He reported feeling feverish once in the morning prior to admission and reported one episode of diarrhoea on questioning. He had no back pain, bladder or autonomic symptoms of note. He was on no regular medications. He did not smoke, and drank alcohol occasionally.

On examination, he was afebrile, tachycardic (heart rate $110 \mathrm{bpm}$ ) and had bilateral crepitations to the mid-zones on lung auscultation. His oxygen saturation was $98 \%$ on air and respiratory rate was 18 breaths/min. Limb examination revealed reduced tone with symmetrical weakness of $4 / 5$ on the Medical Research Council (MRC) Power Grading Scale in upper and lower limbs (table 1). He had diminished tricep reflexes and absent bicep, supinator, knee and ankle reflexes bilaterally. Pinprick sensation was impaired to the right midfoot and left ankle, with impaired vibration sense to the hips bilaterally. Coordination was grossly normal. Cranial nerves were intact.

After 24 hours, his lower limb power had reduced to $3 / 5$ proximally and $2 / 5$ distally (table 1 ) and all limb reflexes were absent. The overall impression was of a progressive flaccid symmetrical sensory and motor neuropathy.
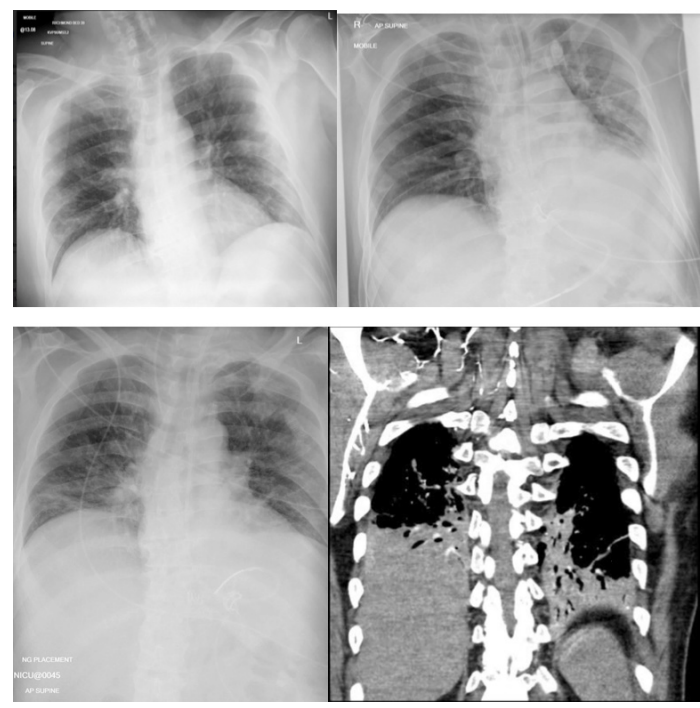

Figure 1 Chest imaging - chest X-ray (CXR) on admission (top left), CXR on day 3 (top right), CXR on day 7 (bottom left) and Computed Tomography Pulmonary Angiogram (CTPA) on day 7 (bottom right). 


\begin{tabular}{|c|c|c|c|c|}
\hline & \multicolumn{4}{|c|}{ Power (MRC Grading) } \\
\hline & \multicolumn{2}{|c|}{ On admission } & \multicolumn{2}{|c|}{ After 24 hours } \\
\hline & Right & Left & Right & Left \\
\hline \multicolumn{5}{|l|}{ Upper limb } \\
\hline Shoulder abduction & 4 & 4 & 4 & 4 \\
\hline Elbow flexion & 4 & 4 & 4 & 4 \\
\hline Elbow extension & 4 & 4 & 4 & 4 \\
\hline Wrist extension & 4 & 4 & 4 & 4 \\
\hline Wrist flexion & 4 & 4 & 4 & 4 \\
\hline Finger extension & 4 & 4 & 4 & 4 \\
\hline Finger flexion & 4 & 4 & 4 & 4 \\
\hline Thumb abduction & $4-$ & $4-$ & 4 & 4 \\
\hline \multicolumn{5}{|l|}{ Lower limb } \\
\hline Hip flexion & 4 & 4 & 3 & 3 \\
\hline Hip extension & 4 & 4 & 3 & 3 \\
\hline Knee flexion & 4 & 4 & 3 & 3 \\
\hline Knee extension & $4+$ & $4+$ & 3 & 3 \\
\hline Dorsiflexion & 3 & 3 & 2 & 2 \\
\hline Plantarflexion & 3 & 3 & 2 & 2 \\
\hline Great toe dorsiflexion & 3 & 3 & 1 & 1 \\
\hline
\end{tabular}

MRC, Medical Research Council.

\section{INVESTIGATIONS}

On admission, blood tests were significant for lymphopenia $\left(0.9 \times 10^{9} / \mathrm{L}\right)$, thrombocythaemia $\left(490 \times 10^{9} / \mathrm{L}\right)$ and a raised $\mathrm{C}$ reactive protein $(25 \mathrm{mg} / \mathrm{L})$. Renal profile, electrolyte, serum Angiotensin Converting Enzyme (ACE), $\mathrm{B}_{12}$, folate, thyroid and clotting functions were all within the normal range. Antinuclear antibody, antineutrophil cytoplasmic antibodies, anti-ganglioside antibodies, syphilis serology and blood-borne virus screen (HIV, hepatitis B and hepatitis C) were negative. His chest X-ray on admission (figure 1) showed no convincing consolidative change, infiltrates or ground-glass shadowing. His SARS-CoV-2 (COVID-19) RNA nasopharyngeal swab was positive. He was admitted with suspected GBS secondary to COVID-19, with a Modified Erasmus GBS Outcome Score of $4 .^{6}$

A lumbar puncture revealed high cerebrospinal fluid (CSF) protein $(0.51 \mathrm{~g} / \mathrm{L})$ with normal glucose and cell counts. No organisms were found on gram staining and viral PCR, including SARS-CoV-2 RNA, was negative.

Nerve conduction studies were carried out on day 2 of admission with a Dantec Keypoint Focus portable system with single constant current stimulator. Stimulation was performed with a bipolar stimulator employing $0.1 \mathrm{~ms}$ duration squared pulses and variable intensity up to $100 \mathrm{~mA}$. For the recording of motor conduction studies, surface electrodes (Ambu neuroline 70001$\mathrm{SC} / 12$ ) were placed according with the muscle belly-tendon standard criteria. Ground surface electrodes (Ambu neuroline 71415-M1) were placed between the stimulating and recording point. Similarly, sensory nerve action potentials were obtained with surface electrodes after distal stimulation (orthodromic technique). Initial latency, duration and base to peak amplitude were calculated for sensory nerve action potentials and compound muscle action potentials. F-wave latencies, when present, were measured from the onset of the compound motor action potential to the onset of the F-wave.

Nerve conduction studies revealed reduced conduction velocity and prolonged distal motor latencies in motor and sensory nerves in the upper and lower limbs with more marked
Table 2 Motor and sensory nerve conduction studies

\begin{tabular}{|c|c|c|c|c|c|}
\hline Nerve & $\begin{array}{l}\text { Latency } \\
\text { (ms) }\end{array}$ & $\begin{array}{l}\text { Amplitude } \\
(\mathrm{mV})\end{array}$ & $\begin{array}{l}\text { Conduction } \\
\text { velocity }(\mathrm{m} / \mathrm{s})\end{array}$ & $\begin{array}{l}\text { F-wave } \\
\text { latency }\end{array}$ & Comments \\
\hline \multicolumn{6}{|c|}{ Motor nerve conduction studies } \\
\hline \multicolumn{6}{|l|}{ Medianus motor right } \\
\hline Wrist-APB & 7.20 & 4.3 & & & \\
\hline Elbow-wrist & 14.7 & 1.86 & 41.3 & Absent & $\begin{array}{l}\text { Dispersed } \\
\text { potential }\end{array}$ \\
\hline \multicolumn{6}{|l|}{ Ulnaris motor right } \\
\hline Wrist-ADM & 4.12 & 6.2 & & 40.5 & \\
\hline Ab. elbow-wrist & 12.0 & 2.9 & 44.4 & & $\begin{array}{l}\text { Dispersed } \\
\text { potential }\end{array}$ \\
\hline \multicolumn{6}{|l|}{ Peroneus motor left } \\
\hline Ankle-EDB & 6.67 & 2.7 & & Absent & \\
\hline Pop fossa-ankle & 20.8 & 1.01 & 30.4 & & $\begin{array}{l}\text { Dispersed } \\
\text { potential }\end{array}$ \\
\hline \multicolumn{6}{|l|}{ Peroneus motor right } \\
\hline Ankle-EDB & 7.23 & 2.6 & & Absent & \\
\hline Pop fossa-ankle & 25.7 & 0.23 & 22.3 & & $\begin{array}{l}\text { Dispersed } \\
\text { potential }\end{array}$ \\
\hline \multicolumn{6}{|l|}{ Tibialis motor left } \\
\hline Ankle-AH & 10.4 & 1.68 & & Absent & \\
\hline Knee-ankle & 30.0 & 0.38 & 22.4 & & $\begin{array}{l}\text { Dispersed } \\
\text { potential }\end{array}$ \\
\hline \multicolumn{6}{|l|}{ Tibialis motor right } \\
\hline Ankle-AH & 9.39 & 1.66 & & Absent & \\
\hline Knee-ankle & 24.2 & 0.77 & 29.7 & & $\begin{array}{l}\text { Dispersed } \\
\text { potential }\end{array}$ \\
\hline \multicolumn{6}{|c|}{ Sensory nerve conduction studies } \\
\hline \multicolumn{6}{|c|}{ Medianus sensory right } \\
\hline Digit II-wrist & - & - & - & & $\begin{array}{l}\text { Absent } \\
\text { sensory } \\
\text { nerve action } \\
\text { potential }\end{array}$ \\
\hline \multicolumn{6}{|l|}{ Ulnaris sensory right } \\
\hline Digit V-wrist & 2.45 & 4.0 & 40.8 & & \\
\hline \multicolumn{6}{|l|}{ Radialis sensory right } \\
\hline Forearm-dorsum & 1.64 & 30.8 & 54.9 & & \\
\hline \multicolumn{6}{|l|}{ Suralis sensory left } \\
\hline Calf-latmalleolus & 2.47 & 12.4 & 44.5 & & \\
\hline \multicolumn{6}{|l|}{ Suralis sensory right } \\
\hline Calf-lat. malleolus & 3.74 & 7.9 & 34.8 & & \\
\hline \multicolumn{6}{|c|}{$\begin{array}{l}\text { Peroneus superfic sensory } \\
\text { left }\end{array}$} \\
\hline Lower leg-dorsum & 3.54 & 12.0 & 31.1 & & \\
\hline \multicolumn{6}{|l|}{$\begin{array}{l}\text { Peroneus superficialis } \\
\text { sensory right }\end{array}$} \\
\hline Lower leg-dorsum & 3.84 & 7.3 & 28.6 & & \\
\hline
\end{tabular}

Ab, Abduction; ADM, Abductor digiti minimi; AH, Abductor Hallucis ; APB, Abductor pollicis brevis; $E D B$ Extensor digitorum brevis; Lat, Lateral; Pop, Popliteal.

slowing in the lower limbs (table 2). Motor action potentials showed marked dispersion in their morphology which was more pronounced in tibial and common peroneal nerves (figure 2). F-waves were not obtained from the common peroneal, tibial and right median nerves, and had prolonged latency in the right ulnar nerve. Sensory nerve conduction studies showed reduced velocities in both superficial peroneal and right sural nerves, and were within normal limits for left sural, ulnar and radial superficial nerves. Right median sensory nerve action potentials were absent. These results fulfil the electrodiagnostic criteria for acute inflammatory demyelinating polyneuropathy/GBS.

\section{TREATMENT}

Intravenous immunoglobulin (IVIG) $2 \mathrm{~g} / \mathrm{kg}$ divided over 5 days was started 24 hours after presentation to the hospital. 


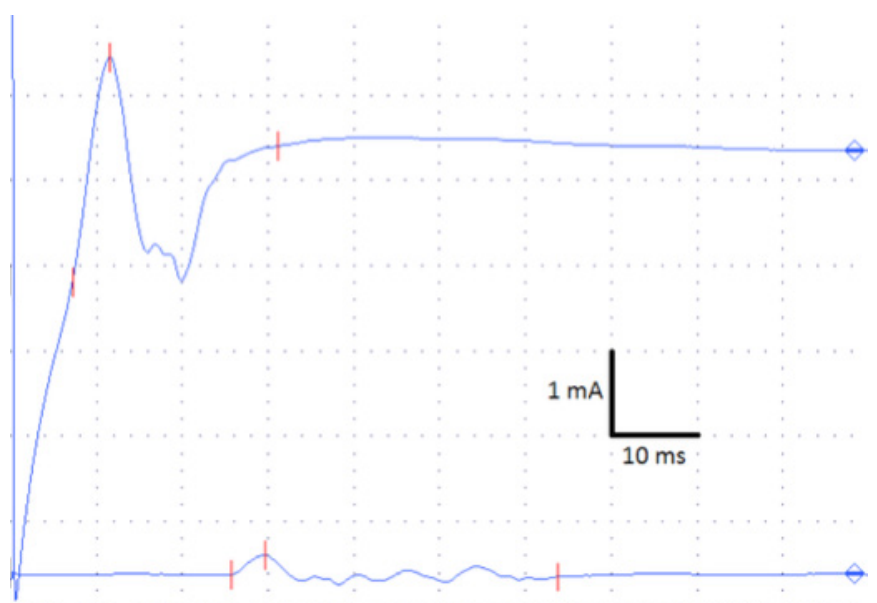

Figure 2 Right common peroneal nerve conduction studies. Traces obtained from extensor digitorum brevis after stimulation of the peroneal nerve at the ankle (upper trace) and on the lateral aspect of the knee (lower trace). Prolonged distal motor latencies (7.23 ms), reduced velocities between both segments $(22.3 \mathrm{~m} / \mathrm{s})$ and dispersion of the proximal potential.

\section{OUTCOME AND FOLLOW-UP}

On day 3 of admission, the limb weakness progressed, he developed swallowing difficulties and vital capacity measurements deteriorated from $4.86 \mathrm{~L}(52 \mathrm{~mL} / \mathrm{kg})$ to $2.07 \mathrm{~L}(22 \mathrm{~mL} / \mathrm{kg})$. His oxygen saturations dropped to $89 \%$ on air and he began to struggle to expectorate sputum. A decision was made to intubate and ventilate the patient at this point. After 1 day in the intensive care unit (ICU), he developed increasing inflammatory markers and left lower lobe consolidation on chest X-ray (figure 1), and was, therefore, started on co-amoxiclav for a potential aspiration pneumonia. He completed a 5-day course of IVIG and a percutaneous tracheostomy was performed on day 6 of his ICU admission. His oxygen requirements increased the following day, a Computed Tomography Pulmonary Angiogram (CTPA) showed bi-basilar consolidation and patchy peripheral groundglass opacities in keeping with classic COVID-19 with no acute thromboembolic disease (figure 1). His oxygen requirements and inflammatory markers have now improved and he is currently being weaned off ventilation.

\section{DISCUSSION}

GBS is an autoimmune condition characterised by rapidly progressive limb weakness, often with sensory and cranial nerve deficits, and can result in significant morbidity and mortality. The syndrome is typically post-infectious, with two-thirds of adult patients reporting respiratory or gastrointestinal infections in the 6 weeks prior to presentation, which are thought to trigger an immune response leading to a neuropathy. ${ }^{7}$ A number of well-recognised antecedent infections have been identified in case-control studies, including bacteria such as Campylobacter jejuni and viruses such as Cytomegalovirus and Epstein-Barr virus. In the case presented, the patient developed significant neurology only 1 week after the development of his cough and myalgia, and his chest deteriorated during his intensive care stay (at day 16 of his illness), with a characteristic CT appearance of COVID-19 viral pneumonia. This raises the possibility of a parainfectious course, similar to GBS cases described in association with Zika virus. ${ }^{8}$ While parainfectious neuropathies may develop as an unusual hyperimmune response, they could also represent a direct toxic or neuropathic effect. Further research is needed to differentiate between these two possibilities in COVID-19 patients.

To date, there have been eight published cases of GBS associated with COVID-19 (a case series of five patients from Italy and a single case report from China, Iran and USA). ${ }^{2-5}$ The Italian series reported that $5(0.42 \%)$ out of 1200 patients admitted to their hospitals with COVID-19 presented with GBS, which is disproportionately high for a rare disease that affects 1.6 per 100,000 person-years (matched for the average age of their cohort). ${ }^{49}$ This case report is adding evidence to the increasing recognition that COVID-19 could be an infectious trigger for GBS. The interval between the onset of symptoms of COVID-19 and the first symptoms of GBS was approximately 7 days, and neurological symptoms evolved rapidly over 3 days. These time windows are in keeping with the Italian series. ${ }^{5}$

The clinical manifestations of GBS are varied, from mild limb weakness to respiratory muscle involvement requiring mechanical ventilation. Studies have found that the severity of GBS is associated with the causative organism, demonstrated by the higher rates of severe axonal forms following $C$. jejuni infection. ${ }^{10}$ As such, it is important to further research the link between COVID-19 and GBS to help with diagnosis and prognostication. Of importance, half of the currently reported cases $(4 / 8)$ have needed mechanical ventilation, higher than the recognised 20\%-30\% in all GBS cases. Despite the small sample size, this could represent an interaction between the COVID-19 pneumonitis and GBS increasing the likelihood of needing respiratory support. Alternatively, this may suggest that COVID-19 is a trigger for a more severe and rapidly progressing neuropathy.

It is imperative that clinicians are aware of this association to avoid delays in diagnosis and to promote early initiation of treatment and supportive care for a condition associated with significant morbidity and mortality. This will become more apparent as more cases are identified and longer term outcome data are available.

\section{Learning points}

- There is emerging evidence of the link between COVID-19 and Guillain-Barré syndrome (GBS); it is important that clinicians think of this to avoid delays in diagnosis and treatment.

- Clinicians are at risk of confirmation bias when assessing patients with shortness of breath during the COVID-19 pandemic. It is important that the neurological system is included in history taking and examination to ensure neuromuscular causes are not missed.

- Currently, the diagnosis and treatment of GBS secondary to COVID-19 are the same as the standard recognised guidelines for GBS.

- Careful monitoring of the respiratory function, using serial forced vital capacity measurements, is essential. As patients with COVID-19 pneumonitis are already at risk of respiratory failure, it is hypothesised that a higher number of GBSassociated patients with this condition will need invasive ventilation. Further research is needed in this area.

- Further research is needed to investigate whether the GBS phenotype associated with COVID-19 follows a parainfectious as opposed to the classically post-infectious course. 
Contributors SW and VCJW contributed equally to the planning, conduct, concept and authorship of the paper and are requesting for joint first authorship. DM-L and MY contributed to the acquisition and interpretation of specialist investigations, clinical supervision and editorial input of the paper.

Funding The authors have not declared a specific grant for this research from any funding agency in the public, commercial or not-for-profit sectors.

Competing interests None declared.

Patient consent for publication Next of kin consent obtained.

Provenance and peer review Not commissioned; externally peer reviewed.

This article is made freely available for use in accordance with BMJ's website terms and conditions for the duration of the covid-19 pandemic or until otherwise determined by BMJ. You may use, download and print the article for any lawful, non-commercial purpose (including text and data mining) provided that all copyright notices and trade marks are retained.

\section{REFERENCES}

1 Mao L, Wang M, Chen S, et al. Neurological manifestations of hospitalized patients with COVID-19 in Wuhan, China. JAMA Neurol.
2 Zhao H, Shen D, Zhou H, et al. Guillain-Barré syndrome associated with SARS-CoV-2 infection: causality or coincidence? Lancet Neurol 2020;4.

3 Sedaghat Z, Karimi N. Guillain Barre syndrome associated with COVID-19 infection: a case report. J Clin Neurosci 2020;4.

4 Virani A, Rabold E, Hanson T, et al. Guillain-Barré syndrome associated with SARSCoV-2 infection. IDCases 2020;4.

5 Toscano G, Palmerini F, Dm RS, et al. Guillain-Barré syndrome associated with SARSCoV-2. N Engl I Med 2020;4

6 Walgaard C, Lingsma HF, Ruts $L$, et al. Early recognition of poor prognosis in GuillainBarre syndrome. Neurology 2011;76:968-75.

7 Doets AY, Verboon C, van den Berg B, et al. Regional variation of Guillain-Barré syndrome. Brain 2018;141:2866-77.

8 Brasil P, Sequeira PC, Freitas Andrea D'Avila, et al. Guillain-Barré syndrome associated with Zika virus infection. Lancet 2016;387:1482.

9 Sejvar JJ, Baughman AL, Wise M, et al. Population incidence of GuillainBarré syndrome: a systematic review and meta-analysis. Neuroepidemiology 2011;36:123-33.

10 Willison $\mathrm{HJ}$, Jacobs BC, van Doorn PA. Guillain-Barré syndrome. Lancet 2016;388:717-27.

Copyright 2020 BMJ Publishing Group. All rights reserved. For permission to reuse any of this content visit

https://www.bmj.com/company/products-services/rights-and-licensing/permissions/

BMJ Case Report Fellows may re-use this article for personal use and teaching without any further permission.

Become a Fellow of BMJ Case Reports today and you can:

- Submit as many cases as you like

- Enjoy fast sympathetic peer review and rapid publication of accepted articles

- Access all the published articles

Re-use any of the published material for personal use and teaching without further permission

Customer Service

If you have any further queries about your subscription, please contact our customer services team on +44 (0) 2071111105 or via email at support@bmj.com.

Visit casereports.bmj.com for more articles like this and to become a Fellow 